\title{
A Flow Approach to Industrial Sites, Firm Dynamics and Regional Employment Growth: A Case Study to Amsterdam-North
}

\author{
Cees Gorter \\ Frank Bruinsma \\ Peter Nijkamp \\ Department of Regional Economics \\ Free University Amsterdam \\ The Netherlands
}

\begin{abstract}
This paper analyses the relationship between spatial dynamics of firms and employment growth in the region. Moreover, it addresses the facilitating or impeding role of (new) industrial sites in the geographical process of firm and job dynamics, while recognising that the spatial dynamics of firms reflect socio-economic developments at both the regional and national level.

To this end, a novel conceptual theoretical-framework based on the flow approach, is developed, through which the relationship between spatial dynamics of firms (entries, exits, and relocations) and changes in regional employment (job creation and job destruction) can be systematically analysed. Moreover, it also allows to assess the generative employment effects of firm moves from and to (newly created) industrial sites in the region.

To demonstrate in practice the usefulness of this new approach for the regional employment effects of spatial firm dynamics (facilitated or hindered by industrial site developments), an empirical application to the area of Amsterdam-North (The Netherlands) will be presented.
\end{abstract}

Correspondence address:

Cees Gorter

Department of Regional Economics

Free University Amsterdam

Boelelaan 1105, 1081 HV Amsterdam

The Netherlands

Tel. (+31) 2044446093

Fax. (+31) 2044446004

2 November 1998

Email: cgorter@econ.vu.nl 


\section{Introduction}

In recent years we have witnessed an increasing interest in new theories of regional economic growth which seek to explain regional development from an endogenous efficiency growth in factor inputs (see for a survey Nijkamp and Poot, 1998). The competitive economic opportunities of an area are increasingly investigated from the perspective of active 'learning regions' (see e.g. Morgan 1997), which offer appropriate land inputs in order to stimulate new business.

This paper focuses on the intricate spatial-economic relationship between the dynamics of firms and that of regional employment. In particular, the role of (newly created) industrial sites in spatial firm dynamics and their employment implications for the region will be addressed. For this purpose, the interaction between firm and job dynamics will be considered first from a theoretical perspective by using the so-called flow approach, and next empirically by (i) assessing the relevant firm and job flows and their correlation for a particular area of the Amsterdam agglomeration (Amsterdam-North), and (ii) analysing the market opportunities for industrial land use in this area.

It goes without saying that spatial movements (relocations) of firms run parallel to the spatial dynamics in employment. A crucial element in this relationship, which will be elaborated at length in this paper, is the distinction between gross and net flows, for both firms and workers (see, for example, Hamermesh, 1993 who surveys recent developments in the labour market literature on this topic). Moreover, it is relevant to consider flows of firms and workers into and out of the region of interest (at the meso level) and to highlight the underlying (behavioral) decisions made by the actors inside and outside the regional arena (Armstrong and Taylor, 1993). In case of (re)location patterns of firms, the decisions to move depend heavily on the attractiveness of the current and alternative regions of location. In addition, other factors play a role as well (at the meso level), such as the regional composition of firm size, the sectoral composition (to which differences in mobility behaviour are related), the ease of enlarging the regional supply of industrial sites, and the willingness of firms to stay in the present region. The order of magnitude of these - and other - factors will determine both the spatial dynamics of firms and the corresponding flows into and out of the regional employment stock. To study this phenomenon appropriately, we introduce in our paper a conceptual-theoretical framework, through which the spatial dynamics of firms (entries, exits and relocations) and dynamics in regional employment (job creation and job destruction) are mutually connected in a systematic way. This will also make it possible to distinguish the generative and distributive components of flows of firms and jobs from and to the region considered.

The structure of the paper is as follows. In section 2, a 'playing field of spatial interaction' will be introduced which includes the key elements of interest in this paper: spatial dynamics of firms and jobs, spatial planning of industrial sites, and spatial economic development. The analytical framework for analysing firm and job dynamics in depth will be elaborated in section 3. An empirical application of this framework to data on firm and job flows in the region of Amsterdam-North will be presented in section 4, in which also attention will be paid to the (future) use of industrial sites in this region. And finally, some concluding remarks are offered in 
section 5 .

\section{Background factors}

Regional economic dynamics is the result of a complex force field (see e.g., Suarez-Villa, 1989). To analyse the role of industrial site development and the evolution of regions in regional employment growth, it is meaningful to discuss first three major spatial-economic themes that are mutually related and together form a 'playing field of spatial interaction' which encompasses the above mentioned topics focal points of interest. In general, the spatial dynamics of firms and jobs have to be regarded simultaneously with the spatial planning of industrial sites, and the general patterns of spatial-economic development (see Figure 1).

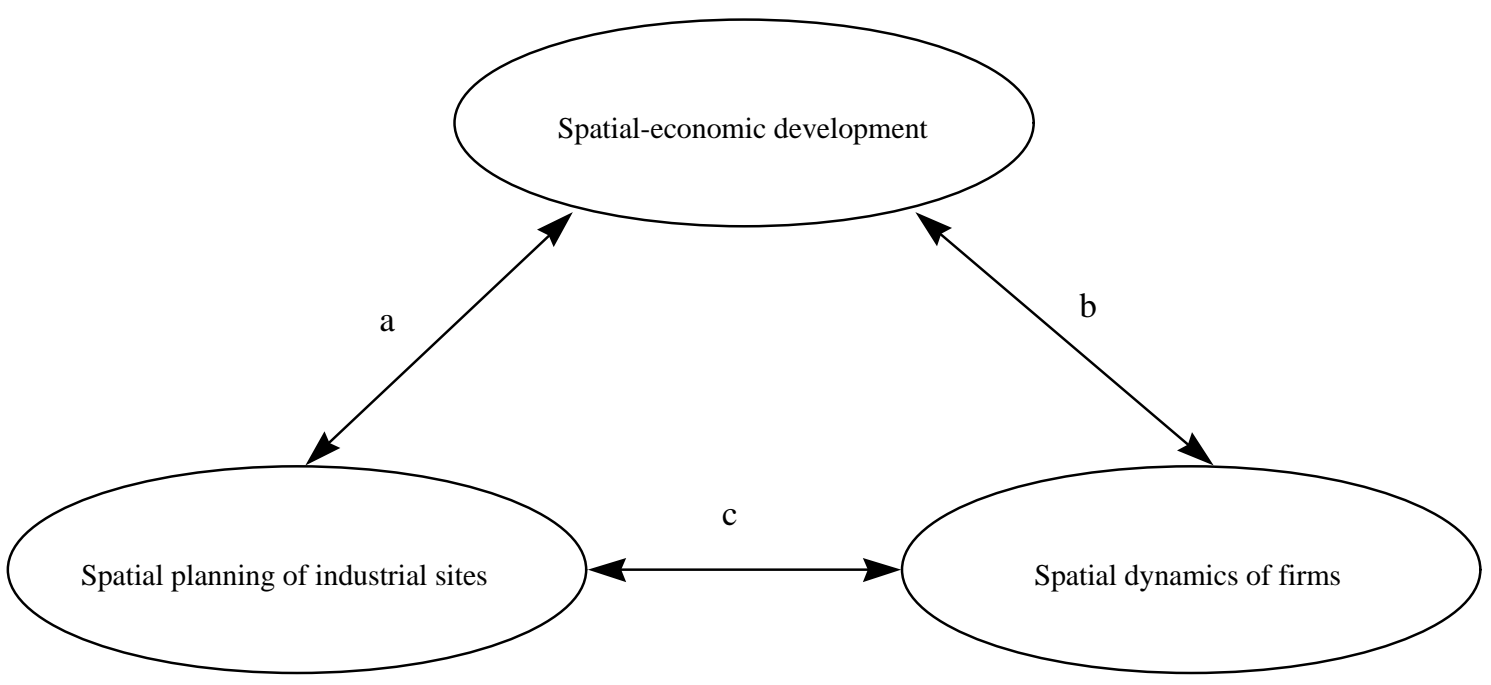

Figure 1 A playing field of spatial interaction

Spatial patterns of economic development at the national level mirror the spatial movements of economic activities (firms and households), and are thereby able to show which regions can be considered as economic core-regions in a particular country and which ones play a secondary role. The actual assignment of regions into core, intermediate and peripheral areas is usually not constant over time; new spatial patterns of industrial and residential concentration and deconcentration influence the hierarchical position of regions in the course of time.

For example, in France the Lille conurbation had a prominent economic position during the period of the steel and mining industry. However, a recession in the European steel and mining industry did the Lille conurbation disappear from the map of prosperous economic regions and became a depressed region. The recent rebirth of the Lille conurbation is initiated by political pressure of former national politicians in local government. They achieved that Lille became the central node in the European high speed rail network in between the densely populated Paris, 
London and Ruhr-area agglomerations. In a far-reaching restructuring process the old city heart is transformed in a modern office centre that attracts many companies, with special attention to cultural and leisure facilities. The centre became the engine for further economic development in the broader Lille region. Another example concerns the Netherlands where one observes that at present the spatial spread of economic activities (measured on the basis of employment densities) is gradually shifting towards the south-eastern part of the country, whereas traditionally the western part has formed the economic core (this phenomenon is sometimes also referred to as large-scale 'urban sprawl'; see, for example, Lambooy and Manshanden, 1992).

Changes in the spatial economic landscape are caused by current and future demands of firms (and households) for land and real estate in various regions. This new 'demand for land' may then lead to the development of industrial sites at these particular locations. This sequence of events (spatial deconcentration - relocation of firms - demand for land) represents the three interrelated factors (or determinants) of spatial interaction (as shown in Figure 1). Now, the mutual relationships between these factors will briefly be addressed.

Spatial planning of industrial sites - as a response of the public sector - may follow or generate new spatial development patterns (a, see Figure 1). In the first case, the role of spatial planning policies is restricted to accommodate the regional/local demand for industrial locations. This also implies that when opportunities to develop industrial sites in particular places are scarce, spatialeconomic development will be impeded (at least in the short run). On the other hand, a pro-active (and controlling) function of spatial planning means that the national or regional government aims to stimulate certain areas by offering industrial sites (possibly targeted at particular sectors) and encourages proper responses of firms. In both cases, it is inevitable that demand and supply are in a permanent adjustment process, since it takes considerable time to make areas suitable for industrial location. Moreover, balanced spatial planning is not just a matter of a quantitative balance between demand and supply for industrial areas, but also qualitative aspects become more and more important (e.g., due to globalisation and internationalisation, locational demands of firms vary across regions and among markets).

Clearly, spatial development patterns and spatial dynamics of firms are mutually related phenomena (b, see Figure 1); on the one hand, the location and relocation behaviour of individual firms influences the spatial configuration of economic activities at the meso (and macro) level (see Pellenbarg, 1996), and on the other hand the differences in regional growth lead to the attraction of new firms towards booming regions and the movements of existing firms from depressed to high-growth regions. For example, some regions are favourable places to settle for firms due to their geographical accessibility, the availability of high quality labour, etc. (see e.g. Porter, 1990). For the Netherlands, it is interesting to note that in general most firms move over rather short distances and that new firm creation - to a large extent - also take place in or nearby economic conurbations (these tendencies in firm (re-)location behaviour are of course connected to the above mentioned process of spatial deconcentration).

Most importantly for the analysis in this paper, we will concisely consider the interaction between spatial adjustment behaviour of firms (including locational choices of new establishments) and 
the planning and development of industrial sites at the regional (or local) level (c, see Figure 1). It is a well-known fact that most relocation decisions of firms are triggered by lack of space at the previous location (see e.g., Rietveld and Bruinsma, 1998). Another frequently observed regularity concerns the local orientation of (especially small- and medium sized) firms when selecting their new location. For example, it turns out that in the Netherlands most firms tend to relocate within a limited area (partly due to psychological barriers in the re-orientation process; see e.g., Pellenbarg, 1985). Of course, larger and/or (inter)nationally oriented firms have a broader search radius and may move to other regions or nations (see, for example, Bruinsma, Gorter and Nijkamp, 1998). Their selection of suitable locations is also influenced by factors such as the access to national and international markets, multimodal accessibility, and availability of transport facilities (e.g., mainports for waterway transport or international hubs). Firms do - of course - also base their relocation decision on the current spatial pattern of known industrial sites and select their favourable site normally from that given choice set (for example, the site that performs best in terms of accessibility or expected cost-effectiveness). On the other hand, the demands of firms for specific areas may lead to a wide array of responses in planning and development activities of local or regional authorities. This may occur in particular when certain areas become so much attractive that an excess demand for land is taking place. Thus also here a clear mutual relationship appears to exist. With this observation, we can 'close the circle' by returning to the spatial patterns of economic development which reflect - at the aggregate level the movements of industries across space, but which are at the same time based on individual decisions on firm location and relocation. These changing spatial configurations of industries have to be matched on the 'market' of industrial sites and this adjustment process is not only influenced by market forces (such as land prices), but also to a large extent by spatial planning of the (local) government (either of a following or a leading nature).

\section{Spatial dynamics of firms and regional employment growth}

\subsection{The spatial flow approach}

In this section, the spatial-economic interaction between the dynamics of firms and changes in employment is analysed by identifying the relevant flows of jobs and firms. The dynamics in regional economic activities is reflected by firms moving in, out and within the region of interest. This migration component of firm relocation has to be complemented with the demography of firms, in particular the start of firms ('birth') and the firms going bankrupt or leaving the market ('death') in order to arrive at a full description of firm flows (see also e.g. Gordijn and Van Wissen, 1994). Changes in firm flows will lead - together with the growth and decline patterns of existing firms in the region - to changes in job flows.

In order to analyse properly the relationships between the (spatial) dynamics in firms and jobs in general, and to investigate the role of (newly created) industrial sites in the dynamics of regional employment in particular, it is necessary to set out more precisely the anatomy of the regional development process at stake. In particular, an important distinction that has to made is between gross and net flows, for both firm and job flows. Figure 2 shows concisely the composition of firm and job flows (i.e., the anatomy of the dynamics) from a regional-economic perspective and 
the way these flows are mutually related.

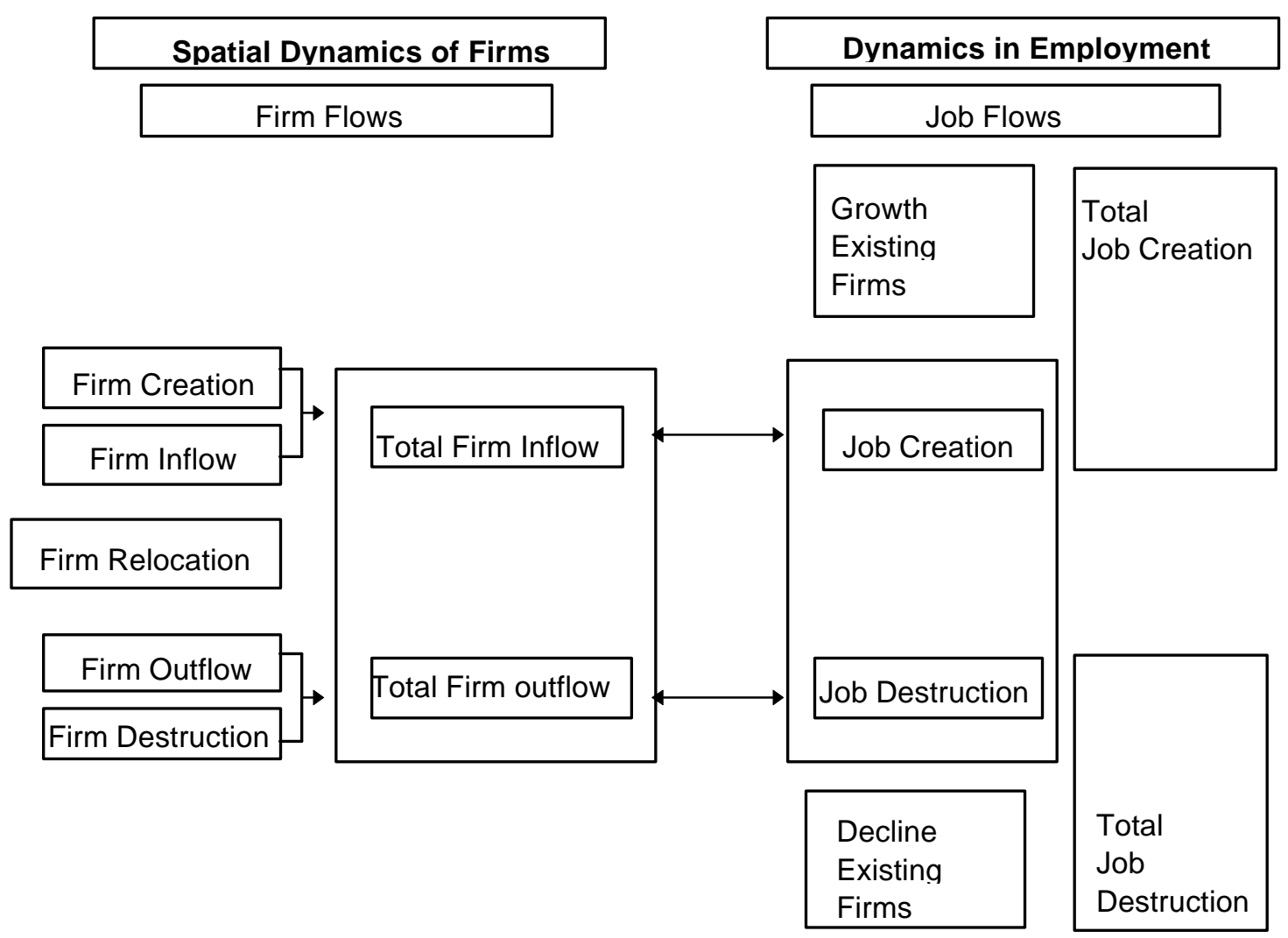

Figure 2 Spatial dynamics of firms and employment growth: an analytical framework for the flow approach

The stock of firms in a region is changing over time due to (i) firms moving in and out of that region, and (ii) firm creation and destruction in that region. Total regional firm inflow (i.e., the sum of moving-in and creation) is directly connected to job creation (by the new firms) in that region, and the same applies to total regional firm outflow and its corresponding regional job destruction. Taking together, the connection becomes clear (see also Figure 2) between the gross firm flow (i.e., the sum of total firm inflow and total firm outflow) and the gross job flow (i.e., the sum of job creation and job destruction). Two crucial points need to be emphasised here (and will be further elaborated in the sequel):

(1) the gross regional firm flow does not include relocations of firms inside the region ${ }^{1}$, and

(2) the gross job flow can be defined in two ways: either with or without the growth and decline of employment in existing firms in the region.

${ }^{1}$ It would only be useful to include these flows in our framework if, and only if firms simultaneously move within the region and expand or reduce their workforce. 
A different terminology with respect to the spatial dynamics of firms, that is often used in the literature on regional economic development, may in fact be misleading when applied to the analysis of the link between firm and job flows in a regional context. This may happen when gross regional firm flows are regarded to consist of two parts, the sum of regional firm creation and firm destruction (turbulence flows) and the so-called mobility flows which are formed by firms moving in, out and within the region of interest. Of course, regional turbulence (creation and destruction) and regional mobility flows may perfectly indicate the extent to which firm movements occur in a region, but these concepts are not useful to analyse the causal economic (employment) effects of firm flows. For example, a high figure for the sum of mobility flows and turbulence flows does not have to be associated with clear growth patterns for the regional stock of firms nor will it necessarily coincide with a positive net change in the number of firms. It turns out from the discussion above that when analysing the role of industrial sites in regional employment dynamics attention should be paid to the following two key questions:

(1) The choice of the spatial level of analysis: what is the size of the region of interest? This may vary from a particular (newly created) industrial site, the neighbourhood, the city or municipality, the district or province up to the level of the nation. Empirical research is usually based on administrative areas (cities or provinces) due to reasons of data availability.

(2) The impact of incumbent firms: how to deal with the effect of existing firms on employment dynamics in the region of interest ? Obviously, this component of firm expansion (or contraction) does not contribute to the spatial dynamics of firms, but the growth or decline of employment will in practice be substantially affected by the development patterns of existing firms in the region. However, it is somewhat difficult to find out whether these changes in employment are fully autonomously determined or to some extent influenced by the fact that some firms enter or leave the region (e.g., giving rise to agglomeration economics).

Table 1 Concepts of firm and job flows in a spatial perspective

\begin{tabular}{||l|l|l||}
\hline $\begin{array}{l}\text { variable of interest -> } \\
\text { concept: }\end{array}$ & $\begin{array}{l}\text { regional dynamics } \\
\text { of firms }\end{array}$ & $\begin{array}{l}\text { regional dynamics } \\
\text { in employment }\end{array}$ \\
\hline Narrow-based & $\begin{array}{l}\text { firm flow }= \\
\text { inflow and outflow }\end{array}$ & $\begin{array}{l}\text { job flow }= \\
\text { job creation and job } \\
\text { destruction related } \\
\text { to in- and outflow } \\
\text { of firms }\end{array}$ \\
\hline Broad-based & $\begin{array}{l}\text { job flow-plus }= \\
\text { total job creation and } \\
\text { total job destruction }\end{array}$ \\
\hline
\end{tabular}

It seems therefore appropriate for the analysis of the interaction between regional firm dynamics and regional employment growth to introduce an explicit distinction between regional dynamics in 
either a broad or a narrow sense (see Table 1). Regional firm dynamics in a narrow sense includes firm creation and destruction flows and flows related to firms moving in and out of the region. If we add the relocation firm flows (within the region) to this concept, we arrive at the regional firm dynamics in a broad sense (which also equals the sum of turbulence and mobility flows). In case of regional employment changes, the 'narrow-based' concept includes job creation and job destruction (as directly related to firms coming in or out of the region), whereas the 'broad-based' concept consists of total job creation and total job destruction (thus including the jobs created or destroyed in existing firms). In Table 1, we summarise the above mentioned concepts of flows.

\subsection{The relationship between firm and job flows}

The next step in the analysis of the consequences of available (partly new created) industrial sites in the region for employment dynamics in that region is to put forward and discuss four potential options to consider the relationship between spatial dynamics of firms (entries, exits, and relocations) and in regional employment growth (job creation and job destruction) in general, and between gross/net firm flows and gross/net job flows in particular. In option 1, the area of interest is purely concerned with the newly created industrial sites in the region, whereas in the other three options the focus is on the region in which the industrial sites are located. So we subsequently consider the following options:

$\begin{array}{llll}\text { Option 1: } & \text { Firm inflow } & \Leftrightarrow & \text { Job inflow } \\ \text { Option 2: } & \text { Firm flow } & \Leftrightarrow & \text { Job flow } \\ \text { Option 3: } & \text { Firm flow } & \Leftrightarrow & \text { Job flow-plus } \\ \text { Option 4: } & \text { Firm flow-plus } & \Leftrightarrow & \text { Job flow-plus }\end{array}$

Option 1 The newly created industrial sites:

firm inflow related to job inflow

In this case, our general scheme of flows (see Figure 2) simplifies greatly. Obviously, firms locating at the newly created industrial sites are new firms; the outflow of firms and firms moving within the area are non-existent. This also implies that the gross firm flow equals the net firm flow. Jobs related to the new firms form the gross - and also the net - job flow. Clearly, a positive relationship emerges between the gross (net) firm flow and the gross (net) job flow.

\section{Option 2 The industrial sites in a regional context:} firm flow related to job flow

When considered in a regional context, (new) industrial sites offer (additional) space for economic activities within the region. The firm flows emerging in this new situation can be directed both into and out of the region (flows within the region, i.e. the relocation flows, are excluded from the analysis in this option). The net firm flow can be positive or negative, dependent on the magnitude of the four underlying components, namely firm creation, firm inflow, firm destruction and firm outflow (see also Figure 2). A positive result for the net firm flow reflects the fact that sufficient land for industrial sites is offered in that region to accommodate this net growth in the stock of firms. For the outcome of the net job flow, a similar uncertainty (like for firms) arises regarding its sign, especially because also the average size of 
the firms moving in and out of the region may differ. So, it becomes clear that the correlation between the net firm flow and the net job flow is not necessarily positive, whereas the gross firm flow and the gross job flow will be positively related by definition.

\section{Option 3 The industrial sites in a regional context: firm flow related to job flow-plus}

The difference with the previous option is that now also job creation and job destruction of existing firms in the region are taken into account to determine gross and net job flows. Most likely, the absolute value of both the gross and the net job flow will be higher, because the 'growth/decline'-components usually outnumber the 'creation/destruction'-components related to firms moving in/out of the region. The important issue in this option is how to interpret a positive correlation between the net firm flow and the net job flow-plus. On the one hand, it is unclear to what extent this positive correlation is due to the net growth in jobs of those firms that actually moved from and to the industrial sites. It might just as well be caused by the net growth of jobs in existing firms. So it is now more difficult to consider the direct function of industrial sites in the observed dynamics of regional employment (job-flow plus). On the other hand, existing firms might benefit (in the long-run) from the moving patterns of (new) firms to the (newly created) industrial sites, and then their employment growth pattern would be partly due to the economic impulse put forward by the additional supply of space for industrial activities. So, in a way, option 3 shows the maximum effect of spatial dynamics of firms (facilitated by industrial site development) on regional employment dynamics (e.g., measured via the number of additional jobs per firm), whereas option 2 gives the minimum value of this effect.

\section{Option 4 The industrial sites in a regional context:}

firm flow-plus related to job flow-plus

Basically, this option is discussed here to argue that it of no use for analysing the employment effects of spatial firm dynamics in response to industrial site development (however, this option appears to be applied frequently in practice). As we stated before, the relocation flow of firms should be excluded from the analysis, because it will overestimate the relevant spatial dynamics on the firm-side. A severe flaw in the analysis is made when in this option the job flows stemming from relocation flows would erroneously be counted as new jobs, and hence included in the job flow-plus component ${ }^{2}$. To sum up, this option is either equivalent to option 3 (when looking at net flows) or not useful at all when employing the firm flow-plus concept.

\subsection{Employment potential}

As discussed in Section 2, the availability of industrial areas in a region will affect the economic growth of that region. Excess supply of industrial sites is not likely to lead to higher regionaleconomic growth rates, but an unmatched demand for land by firms will frustrate the exploitation of the economic potential of that region. Hence, regional growth depends on spatial planning policies that influence the pace and composition of industrial site development. So the questions

\footnotetext{
${ }^{2}$ Too often it happens in practice that policy-makers make use of the popular slogan that 'new space for industrial activities benefits regional employment substantially', but in their 'back of the envelop'-calculation they (erroneously) include the job gains related to firm relocation flows within the region.
} 
is: what determines the employment potential of industrial sites in a region? We note in passing here that employment potential is defined as the regional potential to attract new firms offering new jobs. Most importantly, the prosperity of the regional economy plays a role in this context. If the current employment density is high from a spatial perspective and the regional economy is booming, the demand for land by (new) firms will be high and consequently, the employment potential of (new) industrial sites is also high. Besides quantitative shortages of land for industrial activities, qualitative discrepancies in this land market might be essential too. For example, the employment potential of an industrial site is likely to be higher in regions with a good image as perceived by firms (see Pellenbarg, 1985). Another determinant that is worth mentioning concerns the particular geographical location of the site in the region. This factor influences the site's attractiveness, since locations differ in aspects like (road) accessibility, facilities, settlement of other firms in this area, etc. (see e.g., Bruinsma, 1994). More in particular, the sectoral composition and the average size of the firms that are already settled in the area are important in this respect. It is a well-known fact that new industrial sites are to a large extent filled by firms located in the vicinity of the site and which have grown rapidly in recent years and hence have a need for more space. This observation takes us back to the core question of this paper, that is how to determine properly the net employment effect of firm moves from and to (new) industrial sites in a regional context. We concluded that such movements within the region that lead to the settlement at other sites should not be counted as employment gains. The firm's relocation movements just give rise to redistributive employment effects and do not yield any generative employment effects. Obviously, the decomposition of employment gains into generative and redistributive parts depends on the spatial level of analysis chosen: the lower the spatial level the higher the generative employment gains of firms moving from and to (newly created) industrial sites will be. We will now offer an empirical study to illustrate the above observations.

\section{The case of Amsterdam-North: an empirical illustration}

\subsection{Introduction}

In this section we will test empirically the analytical framework as given in figure 2 by analysing the firm flows and related job developments in Amsterdam-North, defined as the part of the municipality of Amsterdam located north of the river IJ (see Figure 3). This part of the agglomeration has in the past decades not been able to gain its share in the overall economic development in the Amsterdam region. Besides in the city centre, the main economic activities of the Amsterdam agglomeration shifted increasingly towards the southern and south-western part of the region. This region is best connected to the other major Randstad cities (Rotterdam, The Hague and Utrecht) and close to the national airport Schiphol.

Before turning to the main issues of this paper, that is the firm and job flows in the region of Amsterdam-North, and their distributive and generative components (see section 4.4), we will briefly in Section 4.2 sketch the general regional economic conditions in (the surrounding of) Amsterdam-North in the past decade and address thoroughly in Section 4.3 the developments in the spatial planning of industrial sites in the Amsterdam area (and Amsterdam-North in particular) to assess the (future) conditions on the market for industrial land. 


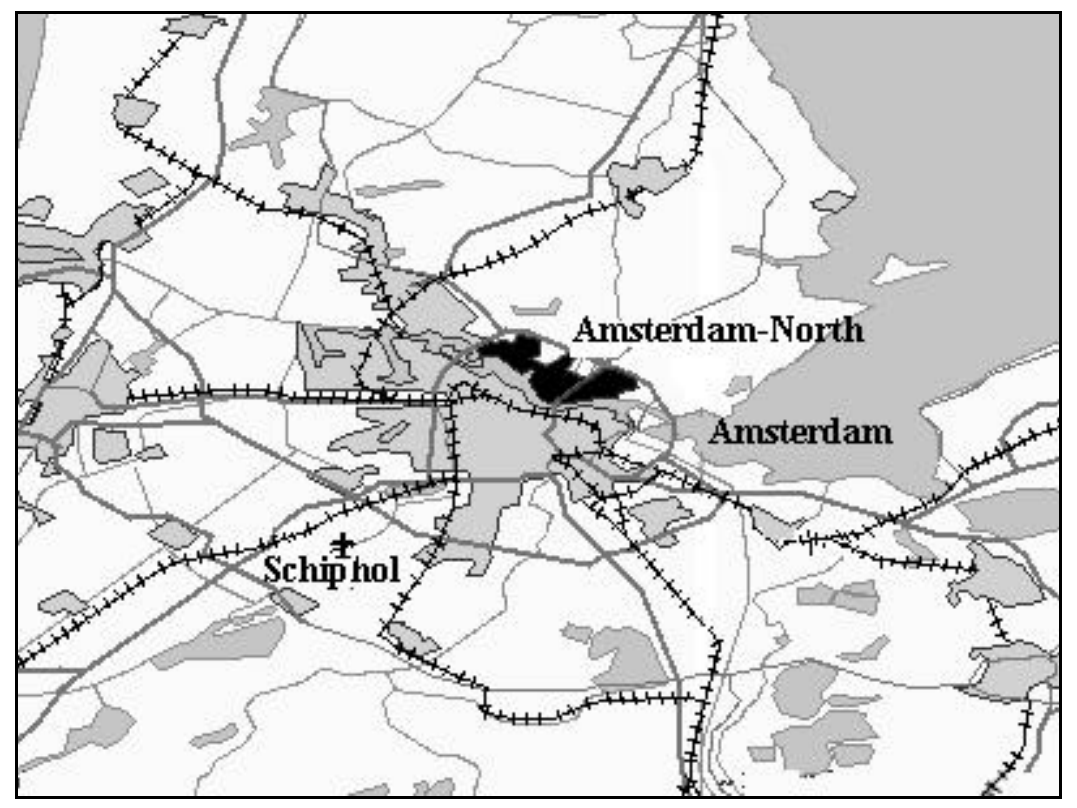

Figure 3 The Amsterdam region

\subsection{The regional economic context}

For the analysis of the regional economic context, extensive use has been made of the 'Survey Regional Firm Development' (ERBO) which is yearly held by the Chambers of Commerce in the Netherlands (KvK Amsterdam, 1985-1992) among most firms in a given area. For the period 1985-1992 the developments in turnover, firm investments, the number jobs and other indicators of firms are given at the level of four digit postal zones. The analysis is focused on two levels of spatial aggregation: the area of Amsterdam-North and the broader defined region of AmsterdamZaanstad (see Figure 3).

In Amsterdam-North the small firms (less than 50 employees) are over-represented compared to the regional structure of Amsterdam-Zaanstad. Within this group of small firms the sectors trade, manufacturing and business services are well represented $(25.9 \%, 27.6 \%$, and $32.9 \%$ of all firms, respectively).

The development in turnover for the period 1986-1992 of the large firms in Amsterdam-North is relatively positive compared to the growth of the turnover of all large firms in the AmsterdamZaanstad region. However, as mentioned above, the absolute number of large firms in this area is rather small. The development in the growth in turnover of small firms in Amsterdam-North is during the period 1985-1992 equal to the trend as measured in the broader Amsterdam-Zaanstad region. However, there are some sectoral differences. The growth in turnover of firms in the sectors trade and manufacturing are in this period well above the growth in those sectors in the wider region, whereas the growth in turnover of firms in the business service sector is clearly below the broader region average.

In general, there is at the firm level a causal relation between the growth in turnover and the development of employment (see Gorter et al., 1997). However, in this case study the growth of employment in larger firms is below the regional average, whereas the growth in employment in 
small firms is above the regional average for small firms. This indicates relatively low employment dynamics in large firms compared to the employment dynamics of small firms in Amsterdam-North. In particular small firms in the trade sector show a relatively fast rise in employment compared to the pattern observed in the Amsterdam-Zaanstad region for such firms. In the period 1988-1992 also the growth rate of jobs in small firms in the business services sector, and to a lesser extent in the manufacturing sector, are above the respective growth rates in the Amsterdam-Zaanstad region.

Finally, it appears that in the period 1990-1992 $75 \%$ of all employers in Amsterdam-North have invested in their firm, whereas the average is 10 percent point lower for the Amsterdam-Zaanstad region. The level of replacement investments is 8 percent points higher in Amsterdam-North, whereas the level of expansion investments is equal to the regional average.

To summarise: the small firms - in particular active in the trade and business service sector - are showing a relatively dynamic pattern in Amsterdam-North if we analyse the increase in turnover and job development. On the whole, Amsterdam-North does apparently not perform economically less than the average of the Amsterdam-Zaanstad region.

\subsection{The spatial planning of industrial sites}

In this section, the availability of the (future) supply of industrial sites is analysed for the Amsterdam-North area itself and its surrounding area, the Amsterdam region (municipality of Amsterdam). Some introductory remarks are first in order. First, it is important to identify different types of industrial sites, because the use of those sites is quite different. We identify three types: harbour 'wet' sites, industrial 'dry' sites $^{3}$, and office sites. Harbour sites are most extensively used and offer a low job/ $\mathrm{m}^{2}$ ratio. Industrial sites can be used by quite some different economic activities which means that the range in job $/ \mathrm{m}^{2}$ ratio's is rather diverse (distribution and storage activities offer low job/ $\mathrm{m}^{2}$ ratio's; labour intensive industry need a relatively high one). On office sites high-rise buildings are constructed offering employment with high job/ $\mathrm{m}^{2}$ ratio's. These sites are most intensively used. Furthermore, it is essential to distinguish between new sites and restructured sites.

\section{(i) The demand and supply of industrial sites in the Amsterdam region}

In the Amsterdam region, on average 44 hectares of harbour sites are brought into use in the period 1988-1993. However, the annual amount ranges from less than 20 hectares in 1993 to more than 80 hectares in 1989. The pace in which industrial sites are put into use is rather stable: on average 11 hectares per year in the period 1975-1992. The amount of office sites brought into use is with an annual average of about 2 hectares quite low; however, as mentioned above, the use of these sites is intensive (DRO, 1995b).

The stock of sites which can be bought on the market is large. In January 1994 the total stock of sites in the Amsterdam region was 801 hectares of which 286 hectares was direct available (the remaining 'indirect' stock can be made available within five years). The municipality was negotiating over 80 hectares of the direct available stock with firms that claimed to be interested to locate on these sites. However, only 38 hectares is brought into use by these firms: so over 50 $\%$ of the negotiations fails to succeed. Over three quarters of the available stock is located in the

\footnotetext{
${ }^{3}$ Note that in the sequence this type of site is referred to as industrial site (but including 'dry' sites only).
} 
south-western part of the agglomeration (see figure 3). However, the spatial development plans of the municipality of Amsterdam show that over 50 percent of the sites to develop in the near future (the 'soft' stock) is located in Amsterdam North.

Before this 'soft' stock will be developed, the direct and indirect available stock (the 'hard' stock) has to be sold. Although 38 hectares was sold in 1994, per January 1995 the stock ('hard' and 'soft') has increased to 839 hectares (DRO, 1995a).

Until now we have purely dealt with the stock of new sites. We also have to consider the possibility of restructuring old sites. The municipality has planned to restructure in the near future 12 hectares office site, 41 hectares industrial site, and 25 hectares harbour site. These 78 hectares should be added to the stock of new sites (see table 2) (DRO, 1995a).

Table 2 The stock of sites as of January 1995 (in hectares)

\begin{tabular}{llccl} 
& & 'hard' stock & 'soft' stock & $\begin{array}{l}\text { restructuring } \\
\text { sites }\end{array}$ \\
\hline harbour & direct & indirect & & 25 \\
industrial & 174 & 180 & 13 & 41 \\
office & 59 & 207 & 108 & 12 \\
total & 30 & 30 & 38 & 78 \\
\hline
\end{tabular}

Source: DRO (1995a)

The municipality has estimated that in the period 1995-2005 the annual demand for sites will fall in between 40 hectares (approximately 3 hectares office site, 16.8 hectares industrial site, and 20.5 hectares harbour site) according to a low economic growth scenario and 60 hectares (4.3 hectares, 24.8 hectares, and 31 hectares, respectively) according to a high economic growth scenario (DRO, 1995b). The policy of the municipality is to keep a strategic stock ('iron' stock) in reserve which covers the expected demand for the coming five years (DRO, 1995b). So the claims on the stock have two components: the expected demand and the strategic stock (table 3 ).

Table 3 Estimated demand for sites 1995-2005 (in hectares)

\begin{tabular}{lccccccc}
\hline & \multicolumn{3}{c}{ low growth path } & \multicolumn{3}{c}{ high growth path } \\
& demand & iron & total & demand & iron & total \\
\hline & & & & & & \\
harbour & 205 & 103 & 308 & 310 & 155 & 465 \\
industrial & 168 & 84 & 252 & 248 & 124 & 372 \\
office & 30 & 15 & 45 & 43 & 22 & 65 \\
total & 403 & 202 & 605 & 601 & 301 & 902 \\
\hline
\end{tabular}


As can be seen from table 4 the hard stock covers the demand for each activity according to the low economic growth scenario. However, if the high economic growth will be realised, there will be an insufficient supply which, in case of harbour sites, even cannot be covered fully by the soft stock and the restructuring of old sites. These shortages in stock only occur when the strategic stock still has to be available in the year 2005. Without a strategic (iron) stock the supply of all types of sites by the hard stock is sufficient to cover the demand until 2005: in 2006 there will be an insufficient supply of industrial sites, followed by a shortage in supply of harbour sites in 2007.

(ii) The demand and supply in Amsterdam-North

In Amsterdam North the distribution, transport and construction sectors are well represented. Those activities need much space in relation to the number of jobs they offer. The majority of activities are located on traditional industrial sites. Although there are a number of harbour sites, they are hardly used for 'wet' activities. The Northern IJ Lake is planned to be developed as the major future industrial site in the area (45 hectares soft stock, see table 10) ${ }^{4}$. The office sites $\left(21.100 \mathrm{~m}^{2}\right.$ direct available and $30.400 \mathrm{~m}^{2}$ soft stock) will mainly become available for shops, banks, public services et cetera. Therefore, we will mainly concentrate on the development of industrial sites in Amsterdam-North (see Table 5).

Table 4 Estimated demand versus supply based on the 'hard' stock 1995-2005 (in hectares)

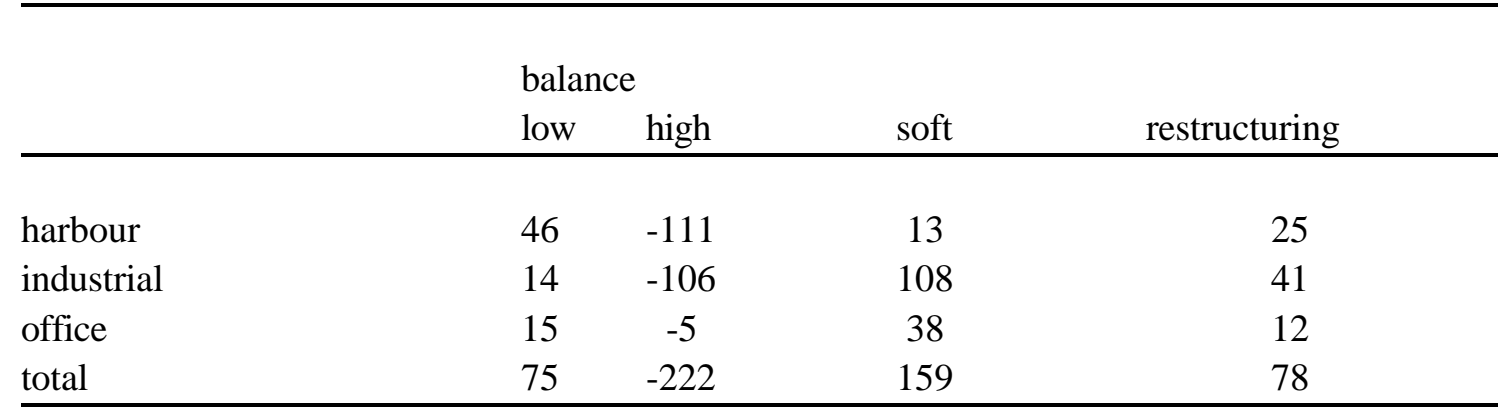

Table 5

Stock of industrial sites in Amsterdam North (in hectare)

\begin{tabular}{lccc}
\hline & \multicolumn{2}{c}{ 'hard' stock } & 'soft' stock \\
& direct & indirect & \\
\hline & & & \\
new sites & 0.2 & 2.1 & 45.0 \\
restructured sites & 6.8 & 18.5 & 29.2 \\
total & 7.0 & 20.6 & 74.2 \\
\hline
\end{tabular}

Source: DRO, 1996

\footnotetext{
${ }^{4}$ This lake will be reclaimed by sand dredged from a new harbour development on the opposite site of the river IJ (the so-called 'Afrika-haven')
} 
When we compare this stock with the average pace in which industrial sites are taken into use in the last 10 years (annually 1.34 hectares), the 'hard' stock can supply the requirements for 15.6 years, with still keeping an 'iron' stock - of the size of the average demand in five years - in reserve. Keeping in mind the large reserve of soft stock, we can conclude that the supply of industrial sites in Amsterdam-North will impose no restrictions on the spatial economic development of the region in general, and the spatial movements of firms into the area in particular.

\subsection{The spatial dynamics of firms and jobs}

The in- and outflow and relocation of firms reflect the spatial dynamics of economic activities within a region. Together with the increase and decrease of employment of existing firms, and the firm creation and firm destruction, the regional dynamics in employment can be analysed (see figure 2).

In this subsection the flows of firms and employment are analysed for Amsterdam-North following the structure of figure 2. Moreover, attention is paid to the generative and distributive effects of spatial firm dynamics. In this case-study movements of firms within the Amsterdam agglomeration (origin or destination Amsterdam-North) are seen as distributive, whereas all other firm movements, national and international, are considered as generative.

\section{(i) Spatial firm dynamics in Amsterdam-North for the period 1989-1993}

For the analysis of the firm and job dynamics we make extensive use of a report of the statistical office of the Municipality of Amsterdam (O+S, 1997). In this analysis the annual firm registers are compared for the period 1989-1994. By comparing the registers of two successive years, all new and disappeared firms in the register could be detected as well as the firm movements within the Amsterdam agglomeration. However, a major consequence is that it is neither possible to make a distinction between the inflow of firms and firm creation, nor between the outflow of firms and firm destruction. This problem is dealt with in an artificial manner. In another report of the statistical office of the municipality of Amsterdam the distinction between new firms 'starters' and the inflow is made as well as the distinction between firm destruction and the outflow of firms for the period 1989-1991 (O+S, 1994). In table 6 we give the shares of inflow versus creation and outflow versus destruction for the period 1989-1991 in Amsterdam-North. We assume that the share for the years 1992 and 1993 are equal to the shares given in table 6.

Table 6 Shares of inflow versus creation and outflow versus destruction in AmsterdamNorth (1989-1991)

\begin{tabular}{lclll}
\hline & & & & \\
& inflow & creation & outflow & destruction \\
firms & 8.3 & 91.7 & 21.7 & 78.3 \\
jobs & 15.8 & 84.2 & 23.2 & 76.8 \\
\hline
\end{tabular}

In table 7 the spatial firm and employment dynamics are given for Amsterdam-North in the period 1989-1993. There is one inconsistency in the table which is not clear from reading the 
report. The stock of firms increases by 497 firms in the period 1989-1993, whereas the balance between total firm inflow and total firm outflow is only 237 firms. This difference can be explained by the huge amount of firms created in this period for fiscal purposes (for instance, by pensioners). Those firms are not economically productive, so that they are not dealt with as firm creations in this study.

Table 7 Firm and employment flows in Amsterdam-North (1989-1993; in absolute numbers)

Stock of Firms 1989

Stock of Jobs 1989

18.491

Creation 1989-1993

firms $\quad 1.290^{*}$

jobs $\quad 5.609^{*}$

Inflow 1989-1993

firms $\quad 438^{* *}$

jobs $\quad 2.579^{* *}$

Total inflow

firms $\quad 1.728$

jobs $\quad 8.188$

Relocation 1989-1993

$\begin{array}{llll}\text { firms } & 557 & \text { Net flow } & \\ \text { jobs } & 3.050 & \text { firms } & 237 \\ & & \text { jobs } & 1.417\end{array}$

Outflow 1989-1993

$\begin{array}{lc}\text { firms } & 519^{* *} \\ \text { jobs } & 2.830^{* *}\end{array}$

Destruction 1989-1993

$\begin{array}{ll}\text { firms } & 972^{*} \\ \text { jobs } & 3.933^{*}\end{array}$
Total outflow
firms $\quad 1.491$
jobs $\quad 6.771$

Net growth jobs new firms after location (inflow 1989-1993) 262

Net growth jobs firms existing 1989-1993

\begin{tabular}{lclc} 
Stock of Firms 1993 & 3.081 & Net growth jobs & 1.813 \\
Stock of Jobs 1993 & 20.352 & Net growth firms & 237 \\
\hline
\end{tabular}

* $\quad$ estimated, see table 6 based on O+S (1994)

** generative inflow/outflow estimated by percentages given table 6 that are based on O+S (1994); distributive inflow/outflow given by O+S (1997)

Source: O+S (1997) 
When we consider the spatial firm movements, over one third of the movements (firms and jobs) concern relocations within Amsterdam-North. The outflow of firms and jobs is larger than the inflow in the period 1989-1993, so there is a negative balance of 81 firms and 251 jobs lost by Amsterdam-North. In the period 1989-1993, 52.9 percent of the average number of firms and 43.4 percent of the average number of jobs are involved in a firm movement $(10.6 \%$ and $8.7 \%$ annually, respectively).

The negative balance of the migration flows of jobs (251) and firms (81) is over-compensated by the balance of firm creation versus firm destruction (1.676 jobs and 318 firms). As a result, there is a positive net flow of 237 firms and 1.417 jobs in Amsterdam-North over the period 19891993. The net growth in jobs of firms already existing in the period 1989-1993 and the growth in jobs of firms moving into Amsterdam North in the period 1989-1993 should be added to the net flow of jobs to reach to the level of the net growth of jobs.

Table 7 gives a complete overview of the absolute flows of firms and jobs. Another way to analyse the flows is to study the relative size of the flows. In other words: what is the size of the flows compared to the stock of firms and jobs?, and: what is the average number of jobs per firm in each flow? The picture emerging from the first question is naturally reproducing the signals obtained from the absolute volumes: first, the outflow is larger than the inflow of firms, but the net flow is positive due to the positive difference between job creation and job destruction, and second, the relocation flow is more than twice as large as the net flow of firms into the Amsterdam-North region. The importance of the second question is that many small firms might offer as many jobs as one large firm. This information is given in table 8 .

On average, relatively small firms are involved in firm movements, firm creation and firm destruction: the share in the stock of firms is larger than the share in the stock of jobs (the number of jobs per firm is below the overall average). Only the inflow of firms from outside the agglomeration contributes less to the stock of firms than that they contribute to the stock of jobs. However, the absolute number of firms moving from outside the agglomeration towards Amsterdam-North is relatively small.

This pattern that small firms are largely responsible for regional dynamics is quite usual. Starting firms often offer employment to only a few people. If the firm is a success in the initial years, the firm will grow relatively fast (also in terms of employment). Fast growth often means that those young firms need space to expand, but this is in most cases not available at the present location and urges them to move. This explains the high mobility of relatively small firms. On the other hand, many young firms fail to succeed and disappear in the first three years of their existence. This explains the relatively high share of firm destruction, in particular of relatively small firms.

The figures presented in Table 8 can be used to estimate empirically the relationship between firm flows and jobs flows in the Amsterdam-North region. As has been indicated in section 3, different options are available to perform this task ${ }^{5}$, and it has also been argued in this respect that the appropriate way to do so is to relate the gross/net firm flow to either gross/net job flow (option 2approach) or to the gross/net job flow-plus, that is based on total job creation and destruction in the region (option 3-approach).

\footnotetext{
${ }^{5}$ Unfortunately, we cannot present the figures on option 1 due to lack of information on the firm and job flows into new industrial sites in Amsterdam-North. In addition, as argued in section 3, option 4 is meaningless (in gross terms) or boils down to option 3 (in net terms).
} 


$\begin{array}{llc}\begin{array}{l}\text { average annual } \\ \text { share of firms }\end{array} & \begin{array}{l}\text { average annual } \\ \text { share of jobs }\end{array} & \begin{array}{l}\text { average number } \\ \text { of jobs per firm }\end{array} \\ (2.872) & (19.486) & (6.8)\end{array}$

\begin{tabular}{|c|c|c|c|c|c|c|}
\hline Creation & 9.0 & & 5.8 & & 4.3 & \\
\hline Inflow & 3.1 & & 2.6 & & 5.9 & \\
\hline distributive & 2.2 & & 1.6 & & 4.8 & \\
\hline generative & 0.8 & & 1.1 & & 9.0 & \\
\hline Total inflow & 12.0 & & 8.4 & & 4.7 & \\
\hline Relocation & 3.9 & & 3.1 & & 5.5 & \\
\hline Destruction & 6.8 & & 4.0 & & 4.0 & \\
\hline Outflow & & 3.6 & & 2.9 & & 5.5 \\
\hline distributive & 1.9 & & 1.7 & & 6.6 & \\
\hline generative & 1.7 & & 1.2 & & 4.4 & \\
\hline Total outflow & 10.4 & & 6.9 & & 4.5 & \\
\hline Net flow & 1.6 & & 1.5 & & 6.0 & \\
\hline Net growth jobs existing firms & -- & & 0.4 & & & \\
\hline
\end{tabular}

Let us first summarise the average annual values of the gross and net flows for the period 19891993, both for firms and jobs in percentages of the average stock of firms and jobs, respectively. So, the figures in Table 9 show that the gross flows are fairly high, especially for firms (more than $20 \%$ annually). We also see positive net flows in all cases which also implies that independent of the option chosen - net firm and net job flows are positively correlated in the Amsterdam-North region (1989-1993) ${ }^{6}$. As regards the difference between option 2 and 3, this is most clearly revealed when we compute on the basis of the net numbers the average number of jobs per firm. It then becomes apparent that option 2 leads to an average net creation of 6.0 jobs per firm, whereas option 3 gives 7.6 jobs per firm on average. In other words, using the broad job-concept of option 3 (including creation and destruction of existing firms) leads, in the case of Amsterdam-North, to an average result which is $27 \%$ higher than that of option 2 (in which the creation-destruction component is excluded). Recall that this level of 7.6 jobs per firm form an upper bound of the effect that can be attributed to the availability of industrial sites in this region, whereas the level of 6 jobs per firm can be seen as a lower bound.

\footnotetext{
${ }^{6}$ Obviously, the gross flows are also positively related in option 2. Note also that - as was conjectured before - the net flow of jobs becomes higher when the creation and destruction in existing firms is taken into account. The warning given in section 3.1 that it would be a severe flaw in the analysis when the jobs flows stemming from relocation flows are counted as new jobs can be illustrated by this example. The adding of the relocation flow would result in a significant overestimation of net flow (5.0 percent in stead of the actual job flow of 1.9 percent).
} 
Table 9 Empirical results for firm and jobs flows in the Amsterdam-North region (in percentages per year; 1989-1993)

\begin{tabular}{|c|c|c|}
\hline $\begin{array}{l}\text { variable of interest -> } \\
\text { concept: }\end{array}$ & $\begin{array}{l}\text { regional dynamics } \\
\text { of firms }\end{array}$ & $\begin{array}{l}\text { regional dynamics } \\
\text { in employment }\end{array}$ \\
\hline Narrow-based & $\begin{array}{l}\text { firm flow }= \\
\text { inflow and outflow } \\
\begin{array}{lc}\text { gross: } & 22.4 \\
\text { net: } & 1.6 \\
& \\
& \text { option } 2 \rightarrow \\
& \text { option } 3 \backsim\end{array}\end{array}$ & $\begin{array}{l}\text { job flow }= \\
\text { job creation and job } \\
\text { destruction related } \\
\text { to in- and outflow } \\
\text { of firms } \\
\text { gross: } \\
\text { net: }\end{array}$ \\
\hline Broad-based & $\begin{array}{l}\text { firm flow-plus = } \\
\text { inflow, outflow and } \\
\text { relocation-flow } \\
\\
\text { gross: } \quad 26.3 \\
\text { net: } \quad 1.6\end{array}$ & $\begin{array}{l}\text { job flow-plus }= \\
\text { total job creation and } \\
\text { total job destruction } \\
\text { gross: } \quad>15.3^{7} \\
\text { net: } \quad 1.9\end{array}$ \\
\hline
\end{tabular}

\section{(ii) Distributive versus generative firm and job flows}

In our theoretical framework we distinguish relocations, distributive and generative firm movements. The relocations within Amsterdam-North were already shown in table 7 and 8 (one third of the movements are relocations within Amsterdam-North). In table 10 the inflow and outflow of firms and jobs are specified in movements between Amsterdam North and the Amsterdam agglomeration and between Amsterdam-North and areas outside the Amsterdam agglomeration.

Table 10 shows that there is a positive migration balance of firms for Amsterdam-North in relation to the Amsterdam agglomeration. However, the outflow of firms to areas outside the agglomeration exceeds the distributive and generative inflow of firms. So, the overall negative outflow of firms is caused by the huge number of firms leaving the Amsterdam agglomeration. This result is in line with the findings of Kemper and Pellenbarg (1997), who show a negative migration balance of firm relocation for all Randstad cities in favour of locations in the intermediate zone of the Netherlands.

Although there is a positive balance in distributive movements of firms, the distributive balance of job movements is negative. Relatively small companies move towards Amsterdam-North, whereas relatively large companies move towards the remainder of the Amsterdam

\footnotetext{
${ }^{7}$ We have unfortunately no data about the number of jobs created in existing growing firms and the number of jobs lost in existing shrinking firms. This means that we have no gross flows of job creation and job destruction for the existing firms in Amsterdam-North.
} 
agglomeration. The net distributive job loss is of the same magnitude as the net job loss caused by the negative generative firm balance. From outside the Amsterdam agglomeration relatively large firms move towards Amsterdam-North compared to the average firm size of firms moving in the opposite direction.

Table $10 \quad$ Origin of inflow and destination of outflow of the firms (1989-1993)

\begin{tabular}{|c|c|c|c|c|c|c|}
\hline & \multicolumn{3}{|c|}{$\begin{array}{l}\text { Amsterdam agglomeration } \\
\text { (distributive) }\end{array}$} & \multicolumn{3}{|c|}{$\begin{array}{l}\text { Out of Amsterdam } \\
\text { (generative*) }\end{array}$} \\
\hline & firms & jobs & jobs/firms & firms & jobs & jobs/firms \\
\hline inflow & $\begin{array}{l}321 \\
(73 \%)\end{array}$ & $\begin{array}{l}1.527 \\
(62 \%)\end{array}$ & 4.8 & $\begin{array}{l}117 \\
(27 \%)\end{array}$ & $\begin{array}{l}1.052 \\
(38 \%)\end{array}$ & 9.0 \\
\hline outflow & $\begin{array}{l}249 \\
(48 \%)\end{array}$ & $\begin{array}{l}1.650 \\
(58 \%)\end{array}$ & 6.6 & $\begin{array}{l}270 \\
(52 \%)\end{array}$ & $\begin{array}{l}1.180 \\
(42 \%)\end{array}$ & 4.4 \\
\hline net flow & 72 & -123 & & -153 & -128 & \\
\hline
\end{tabular}

* estimated by table 6 based on O+S (1994)

Source: O+S, 1997

Another finding is also noteworthy: it turned out that for firms who had chosen for a relocation out of Amsterdam-North, in most cases there were suitable sites available within AmsterdamNorth. However, for the parent companies of those firms strategic motives to locate the firm outside Amsterdam-North appeared to be decisive.

\section{$5 \quad$ Concluding remarks}

This paper has concentrated on the intricate relationship between spatial (regional) dynamics of firms and regional employment growth with a particular focus on the role of spatial planning of industrial sites in this adjustment process. To analyse this issue consistently, we have introduced a conceptual theoretical framework in which spatial firm flows and related job flows are systematically connected to assess the strength of the link between firms and jobs and the net employment effects of spatial firm movements from and to industrial sites in a region. One of the main elements in this assessment procedure has dealt with the role of the relocation flow of firms (firms moving within the region of interest), and its implication for the nature of the employment effects (generative versus distributive). Moreover, we have put forward that special attention in the assessment is warranted for the choice of the spatial level of analysis and the impact of incumbent firms on regional employment dynamics. 
To investigate this topic empirically, an application to the region of Amsterdam has been presented. First, an analysis of the demand-supply conditions on the market for industrial land has put forward that - given the estimated pace in which sites are brought into use and the strategic stock the municipality of Amsterdam prefers - there is enough supply to accommodate the expected demand for industrial land in the Amsterdam agglomeration. For Amsterdam-North in particular, the already developed - or spatially planned - sites appear to offer sufficient supply to cope for many years with the demand as revealed in the past years. It has therefore been concluded that firms that aim to move their plant to the Amsterdam-North area will not be hindered by a shortage of industrial sites.

Next, we considered the extent to which the developments in industrial sites allowed for firm growth (and potentially also job growth) in the Amsterdam-North region. We have used the flowapproach to estimate empirically the precise relationship between firm and job flows in the Amsterdam-North region (for the period 1989-1993). By doing so we obtained the following insights. First, industrial site development in Amsterdam-North permitted an annual net growth of about 50 firms. Notably, this growth of firms occurred despite the fact that more firms moved out of the region than entered it. The relocation flow of firms appeared to be about twice as large as the net inflow of firms and about one third of the mobility flow (during 1989-1993). So, there was no lack of opportunities to relocate within the area and moreover, the location profile of the region was favourable for these firms. The net inflow of firms happened to be positively correlated with the net inflow of jobs: measured in a narrow sense (i.e., excluding the net growth of jobs in existing firms) we found an average net creation of 6 jobs per firm; measured in a broad sense (including this aforementioned component), this figure was $27 \%$ higher (7.6 jobs per firm on average). Further inspection of the firm movements (from and to Amsterdam-North) appeared to shed light on the generative and distributive components of the flows. When regarding flows within the Amsterdam agglomeration as distributive, it is found that $27 \%$ of the firm inflow and 38\% of the job inflow is generative. About half of the outflow of firms moved out of the Amsterdam agglomeration (and took with it almost $60 \%$ of the job outflow). However, for the companies that left the Amsterdam-North region, there were other reasons than the supply of industrial sites that were decisive for their relocation decision. So, in summary, it can be concluded that industrial sites in Amsterdam-North have played a facilitating role in the spatial dynamic process of firms and jobs. 


\section{References}

Armstrong, H. and J. Taylor (1993), Regional economics and policy, Oxford, Allen.

Bruinsma, F.R., C. Gorter and P. Nijkamp (1998), Nomadic firms in a globalizing economy: a comparative study, Tinbergen Institute Discussion Paper, Amsterdam/Tinbergen Institute

Bruinsma, F.R. (1994), The impact of transport infrastructure on spatial patterns of economic activities (in Dutch), Ph.D. Thesis, Free University, Amsterdam,

DRO (1995a), Bedrijfsterreinen in Amsterdam 1995, DRO, Amsterdam.

DRO (1995b), Programma Ruimtelijke investeringen Amsterdam, DRO, Amsterdam.

DRO (1996), Bedrijfslocaties in Amsterdam, DRO, Amsterdam.

Gordijn, H. and L. van Wissen (1994), Demography of firms [in Dutch], Planning, 43, 31-43

Gorter, C., W. Hassink, P. Nijkamp and E. Pels (1997), On the endogeneity of output in dynamic labour demand models, Empirical Economics, vol. 22, pp.393-408.

Hamermesh, D.S. (1993), Labor Demand, Princeton: Princeton University Press

Kemper , N.J. and P.H. Pellebarg (1997), De Randstad een hogedrukpan, Economisch Statistische Berichten, pp. 508-512.

KVK Amsterdam (1985-1992), Enquete Regionale bedrijfsontwikkeling, KvK Amsterdam, Amsterdam.

Lambooy, J.G. and W.J.J. Manshanden (1992), The myth of the big city as the engine of the economy (in Dutch), Economische Statistische Berichten, 1045-1049.

Morgan, K. (1997), The learning region: institutions, innovation and regional renewal, Regional Studies, vol. 31, pp. 491-503.

Nijkamp, P. and J. Poot (1998), Spatial perspectives on new theories of economic growth, Annals of Regional Science, Vol. 32, pp. 7-37.

$\mathrm{O}+\mathrm{S}$ (1994), Verschijnen, verschuiven en verdwijnen van werkgelegenheid in Amsterdam in de jaren 1989 t/m 1991, O+S, Amsterdam.

$\mathrm{O}+\mathrm{S}$ (1996), Bedrijfsverplaatsingen in de regio Amsterdam voor de periode 1990-1994, O+S, Amsterdam.

O+S (1997), Werkgelegenheidsmutaties in Amsterdam tussen 1989 en 1994, O+S, Amsterdam.

Pellenbarg, P.H. (1985), Firm Relocation and Spatial Cognition, Ph.D. Thesis, University of Groningen

Pellenbarg, P.H. (1996), Structure and Development of Firm Migration in The Netherlands, firm migration as a signal of spatial development patterns (in Dutch), Planning, 48, 22-32

Porter, M. (1990), The competitive advantage of nations, New York: The Free Press

Rietveld, P. and F.R. Bruinsma (1998), Is transport infrastructure effective?; transport infrastructure, and accessibility: impacts on the space economy, Springer-Verlag, Berlin.

Suarez-Villa, L. (1989), The Evolution of Regional Economies, Preager, New York. 